Pre-publication version of 'Civilising tastes: from caste to class in South Indian foodways' in Food Consumption in Global Perspective: Essays in the Anthropology of Food in Honour of Jack Goody. Editors: Klein JA, Murcott A. 65-86. Palgrave Macmillan, New York 2014.

\title{
Civilising tastes: from caste to class in South Indian foodways
}

\author{
James Staples, Brunel University
}

\begin{abstract}
$\underline{\text { Abstract }}$
Anthropological explorations of food in South Asia are often framed by theories of caste and ritual purity or pollution, with the highest castes characterised as protecting their purity by accepting food from no-one of lower caste status, and those at the bottom accepting food from anyone. The problem with this focus on caste is not that it is misguided per se; many Hindus do indeed regulate their consumption in relation to such concerns, and a quotidian understanding of caste remains vital in understanding how people in India relate to one another. Rather, the problem is that our focus on caste as the defining social institution of India has obscured social relationships defined by other cross-cutting hierarchies that also, and increasingly, reflect and shape Indian foodways. Drawing on prolonged ethnographic fieldwork in Andhra Pradesh, South India, this chapter is concerned with how class in particular - both in terms of economic status and as a marker of distinction - also has profound implications for what people in South India eat, with whom, and why; particularly in the wake of the economic liberalisation that began in the 1990s and the emergence of new foods and tastes ripe for symbolic appropriation.
\end{abstract}

\section{$\underline{\text { Introduction }}$}


Pre-publication version of 'Civilising tastes: from caste to class in South Indian foodways' in Food Consumption in Global Perspective: Essays in the Anthropology of Food in Honour of Jack Goody. Editors: Klein JA, Murcott A. 65-86. Palgrave Macmillan, New York 2014.

Anthropologists have long recognised that rules and practices concerning food and caste in India are closely intertwined. The ritually highest ranking Hindu castes are characterised as protecting their purity by accepting cooked (or kacca) food from noone of lower caste status, and those putatively at the bottom as accepting food from anyone (see, e.g, Mayer 1960; Marriott 1968; Dumont 1970; Béteille 1996: 56-60; Deliége 1999). Birth-ascribed caste identity is also reflected in what people eat, distinguishing not only between vegetarians from non-vegetarians but between meats eaten and styles of preparation (Deliége 1999:38; Staples 2008). For example, some members of the ritually purist castes - the Brahmins - older women in particular, avoided garlic, onions and other 'heating' ingredients deemed inappropriate for their bodily substance (Lamb 2000: 193; Daniel 1987), while others claimed to adopt a more complex or refined meal structure than their regional peers from other castes. Caste identity, in any case, is perceived of as, in contradistinction to class, as relatively immutable: a social categorisation inherited from one's father that defines whom one might (or might not) marry and which, as Dumont (1970) famously sets out, places one in hierarchical relation to everyone else.

The problem with interpreting food and commensality in relation to caste is not that it is misguided per se. Beyond the mostly low caste people I undertook fieldwork with in South India - out-caste by leprosy as well as in a more conventional sense caste remains important in shaping food consumption, especially in northern India and in Nepal, where Hindu cosmologies appear to be less tempered by the influence of other communities than elsewhere in the region. As Liechty notes, however, even in Nepal, until 2006 a Hindu state, there has been a shift from an earlier caste-based logic of 
Pre-publication version of 'Civilising tastes: from caste to class in South Indian foodways' in Food Consumption in Global Perspective: Essays in the Anthropology of Food in Honour of Jack Goody. Editors: Klein JA, Murcott A. 65-86. Palgrave Macmillan, New York 2014.

social interaction to one based more on class, certainly in the public sphere (2005: 21). But even earlier, as Appadurai pointed out more than 30-years ago in respect of India, food avoidances could also signal 'sect affiliation, life-cycle stages, gender distinctions, and aspirations toward higher status' (1981: 495); all distinctions that went beyond caste.

My point, then, is that our traditional anthropological focus on caste as the defining social institution of India has obscured a range of social relationships defined by other cross-cutting hierarchies - including those of class, gender and age - that also, reflect and shape Indian food ways. The significance of these non-caste based markers of social identity has risen, and continued to rise, in an increasingly globalised India, but without, it bears noting, erasing the importance of caste within identity negotiations. As Goody's seminal work in this area teaches us, we need to interpret food and commensality in relation to historical change (1982: 36); local environmental factors (1982: 95); the wider contexts of food distribution, preparation and consumption (1982: 43); and, more widely still, the world economy (1982: 37). It is in the gaps that emerge between the multiplicity of overlapping but sometimes contradictory hierarchies which develop through these contexts that the meanings of food and relationships centred around it might also be manipulated and re-negotiated in attempts to subvert what are otherwise seen - from a top-down or overly structuralist perspective - as hard-and-fast commensal rules.

This chapter is concerned with how notions of 'class' in particular - a category I begin to untangle in the next section - affect what people in South India eat, with whom, and why; especially in the wake of the economic liberalisation that began in the 
Pre-publication version of 'Civilising tastes: from caste to class in South Indian foodways' in Food Consumption in Global Perspective: Essays in the Anthropology of Food in Honour of Jack Goody. Editors: Klein JA, Murcott A. 65-86. Palgrave Macmillan, New York 2014.

1990s and, with it, the emergence of new foods and tastes ripe for symbolic appropriation. The emergence of a so-called new middle class, I shall argue, has implications for the dietary patterns not only of those identified within that category, but for society more generally. I go on to provide an overview of what is eaten in the area where I conduct my fieldwork - coastal Andhra Pradesh - and then discuss some of the variations within that cuisine and how they are used as markers of distinction.

\section{$\underline{\text { Defining class }}$}

Class has received greater attention in South Asian ethnography in recent years, with a particular focus on what is often termed the 'new middle-class' (Säävälä 2003) or the 'consuming class' (Corbridge \& Harriss 2000:123-4; cited in Fuller \& Narasimhan 2007: 125): a social classification that has emerged in tandem with economic liberal reforms since the early 1990s. Although the differences between caste and class are frequently blurred - a large number of newly middle-class IT professionals in Chennai, for example, are also Brahmins (Fuller and Narasimhan 2007) - class is generally more fluid as a social categorisation, performed as much as ascribed. Used as an index of selfidentity class might also allow ritually lower castes to claim elevated status on the basis of their economic power. ${ }^{1}$

While there has long been a middle class in India, then, it has been changed and expanded in the last 20 years by increased transnational traffic in people, ideas and images. This has 'facilitated the emergence of an increasingly wealthy upper-middle and middle-class populace who not only had access to these previously out-of-reach objects and narratives, but for the first time, could also afford them' (Reddy 2005: 217). 
Pre-publication version of 'Civilising tastes: from caste to class in South Indian foodways' in Food Consumption in Global Perspective: Essays in the Anthropology of Food in Honour of Jack Goody. Editors: Klein JA, Murcott A. 65-86. Palgrave Macmillan, New York 2014.

Its newer members might broadly be defined by their educational attainments and their professional and technical skills (Fuller and Narasimhan 2007: 122; see also Goody 1982: $97,175,183$ et passim), as well as by their capacities to use and embody them in socially acceptable ways (McGuire 2011). They are often characterised in contradistinction to an older, more established middle class as vulnerable and anxious an existential state befitting the employment instabilities of a market-driven economy, rather than the secure public sector posts of the past (Mankekar 1999: 97; Säävälä $2003)^{2}$

Contemporary analyses also tend to explore class in India as performative something learned, shaped and expressed through embodied action - rather than determined, as more strictly Marxist or Weberian interpretations might have it, by access to economic resources and wealth. It is in this context that there has been a focus on the relationship between class, taste and consumption. Class, as Liechty points out, 'is not prior to or outside of discourse and performance but an emergent cultural project wherein people attempt to speak and act themselves... into cultural "reality" or “coherence”.' (2005: 3; see also Dickey 2010; Säävälä 2003; Ortner 2003:13-14). Although much of this work centres on public consumption in general, there has also been attention given to contemporary restaurant culture and public dining (Conlon 1995; Nandy 2004; Liechty 2005; Siegel 2010) as well as to changes in domestic cuisine and commensality (Caplan 2008; Donner 2008). Nearly all these accounts of India's contemporary middle-class, however, envisage such social groupings as predominantly urban, and pay little heed to the role played by those at the peripheries of such groupings, such as the many aspirants to middle class lifestyles I encountered in 
Pre-publication version of 'Civilising tastes: from caste to class in South Indian foodways' in Food Consumption in Global Perspective: Essays in the Anthropology of Food in Honour of Jack Goody. Editors: Klein JA, Murcott A. 65-86. Palgrave Macmillan, New York 2014.

provincial towns and villages in coastal Andhra Pradesh, or who migrated to the cities from the countryside to find work and fulfil other social expectations.

The bulk of my own research has been in the rather atypical context of Bethany, a self-run multi-caste leprosy colony of around 350-families, mostly converts from Hinduism - and in a few cases Islam - to Christianity: a village on the borders of a town with a population of around 60,000 people (see Staples 2007). Significantly, while Bethany dwellers remain poor - many families are still reliant on begging interventions from NGOs have meant that a higher proportion of the younger generation had been educated, at least until the end of senior school, than their local peers from comparable socio-economic backgrounds (see Staples 2012). Increasing numbers of this generation also undertake either vocational training or college degrees post their schooling and this, as will become clear, has had important implications for how they related to food. Assuming that the diets and food sharing habits of such a community were representative of Andhra would be misleading, but during my time in Bethany (around three-and-half years across more than ten visits since 1984) I also dined extensively with contacts in surrounding villages and the local town, as well as accompanying many of my informants on visits to their natal places, where I stayed and ate with their mostly Hindu (and occasionally Muslim) families, the majority of which were still engaged in peasant farming. During a separate period of 16 months' fieldwork in the state capital of Hyderabad, 200-miles west of the village, I also ate in numerous Hindu and Muslim homes across social strata, in so doing gaining a much wider picture of Andhra cuisines (and the particular Mughal-inspired cuisine for which Hyderabad is famed) than had I dined exclusively within Bethany. What my particular work in 
Pre-publication version of 'Civilising tastes: from caste to class in South Indian foodways' in Food Consumption in Global Perspective: Essays in the Anthropology of Food in Honour of Jack Goody. Editors: Klein JA, Murcott A. 65-86. Palgrave Macmillan, New York 2014.

Bethany also draws to attention, however, is the potential for manipulation of meanings attributed to food in different contexts, enabling us to observe how food can change status in a way that an understanding rooted in birth-ascribed caste elides. It also offers evidence of how the status-enhancing culinary practices of urban elites, while beyond the scope of most of most of my informants, nevertheless sat in a complex relationship to their own food ways.

\section{Eating the Andhra way}

Since I started visiting South India in the mid-1980s, the diet of those I worked with both everyday and festival - has centred around rice: two or occasionally three main meals comprising a mountain of boiled white rice and accompaniments. The latter depended on the occasion, the seasonal accessibility of ingredients and the economic status of the diner, but, in general, were most often either a seasonal vegetable pulusu (a wet curry rather than a dry fry), a lentil-based curry (pappu or $d h a l)$, and/or a thin tamarind broth (rasam), followed by chutney and, with the last of the rice eaten, curd or buttermilk. When money was scarce, the dhal first got more watery, and later might be replaced initially by chutney, a smaller quantity of which could flavour more rice than a similar quantity of curry, and, in extremis, just chilli powder, mixed through the rice with water. In more affluent households, and in times of relative plenty, supplements might include a fried vegetable accompaniment and/or a poppadom, or sometimes a banana to round off the meal. The dhal might also be enhanced by the addition of ghee, and households might indulge in a better quality of rice. 
Pre-publication version of 'Civilising tastes: from caste to class in South Indian foodways' in Food Consumption in Global Perspective: Essays in the Anthropology of Food in Honour of Jack Goody. Editors: Klein JA, Murcott A. 65-86. Palgrave Macmillan, New York 2014.

At festival times and life cycle rituals the basic structure of the meal remained consistent, although various forms of fried rice or pulao - infused with coconut, cardamom, cinnamon and other spices - replaced at least a portion of the usual boiled white rice, and puris or other wheat-based items might also be added. Among non-vegetarian groups, like the one I worked with, meat - usually chicken - was also seen as essential, and the curd, otherwise served plain, would be transformed into perugu charu with sliced red onions and green chillis. The spicing also became more complex: to the most basic mix of chilli powder, turmeric and salt, such additions as cinnamon, cloves, ginger and garlic would also be mixed and added as masalas. Freshly prepared gonkora patchidi - a chutney made with the green leaf so associated with the region that it was known as Andhra mata (Andhra's mother) - would also be served as an accompaniment.

In the domestic arena, meat or fish also appeared in Bethany at least on Sundays, and eggs - either hard-boiled and served alongside another curry or cooked as part of a curry dish - might also be served once or twice during the week. In local farming communities, however, where families had less disposable income, I was told that meat was less common: saved mainly for festival days and for important guests, with sometimes whole months passing without any being available. In terms of the meat eaten, although beef - either cow or buffalo meat - was still eaten in well over half of all village households in Bethany ${ }^{3}$ and more widely still in the low-caste Christian hamlets that linked the colony to the local town, in recent years it had been overtaken, for reasons of price and availability, by farmed broiler-chicken. In addition, goat which was popular when I first visited the village in the mid-1980s - had become 
Pre-publication version of 'Civilising tastes: from caste to class in South Indian foodways' in Food Consumption in Global Perspective: Essays in the Anthropology of Food in Honour of Jack Goody. Editors: Klein JA, Murcott A. 65-86. Palgrave Macmillan, New York 2014.

increasingly rare: a scarcity of common grazing land combined with high rearing costs had rendered the meat too costly. These days meat was mostly purchased from stalls in the local market and only on special occasions from neighbours who had reared their own, more expensive but tastier, livestock. Vegetables came either from entrepreneurs within the community who stocked up their trolleys from the market and sold it on from the centre of the village, or direct from the market itself.

As most of those I worked with had below poverty line (BPO) government ration cards - allowing them access to state-subsidised rations of key staple goods limited stocks of rice, sugar, lentils and cooking oil were purchased from a 'ration shop' within the village, supplemented by purchases from open-fronted shops in the local bazaar, where people also bought spices, tea and other provisions ${ }^{4}$. Up until a couple of years ago a number of families also reared buffalo for milk production, although now most milk was purchased from outside dairies, sometimes already pasteurised and sealed in plastic bags, and curd was often sold ready made.

Most cooking, however, was still from scratch: sealed-packets of commercially produced spices were a relatively recent innovation, and there were packet mixes for gulab jamun and pre-mixed sambar powder on the shelves in local shops, but these remained relatively uncommon. Local grocers still weighed out the majority of their products from large gunnysacks into the steel and aluminium storage containers consumers took with them to market, although tea, instant coffee and cooking oil were now commercially packaged, and rice were now mechanically de-husked before sale. Durable foodstuffs such as chutneys, while also commercially available in jars, were usually either made at home or purchased from neighbours who prepared them from 
Pre-publication version of 'Civilising tastes: from caste to class in South Indian foodways' in Food Consumption in Global Perspective: Essays in the Anthropology of Food in Honour of Jack Goody. Editors: Klein JA, Murcott A. 65-86. Palgrave Macmillan, New York 2014.

their own fruit and vegetables and sold them on. The only other readymade packaged foods regularly purchased were items such as sweet white bread and biscuits - eaten with tea and coffee, or by those who are unwell - and boiled sweets and toffees. Even these tended to be bought mainly for special occasions such as prayer meetings and children's birthday celebrations, when they were given out from large basins.

Although the basic rice-with-accompaniments meal structure was consistent throughout the community and was common among local families I ate with elsewhere, some informants spoke of alternative arrangements in their natal places that reflected caste and other distinctions. My research assistant Das, for example, a Brahmin (ritually high caste) originally from Tamil Nadu, stressed that meals in his natal home - even when they were short of money - were more complex than those his wife in the colony now served him, something confirmed when I ate with his relatives in Madras on several occasions. Whereas meat was a mark of prosperity in the village, for vegetarian castes greater affluence was signalled through the number of courses as well as the complexity and quality of ingredients of the individual dishes. The order in which food was eaten also varied across India's regions: where I worked in coastal Andhra, if a meat or fish dish was served it was eaten early in the meal, before the dhal, rasam and other accompaniments; in Kolkata - as I learned from the horrified looks on my hosts' faces when I tucked into the fish and egg stew they had prepared for me before the vegetable and lentil based dishes - it should be eaten last ${ }^{5}$.

It was, however, tiffin - a general term adopted to cover breakfast and other, non-rice based snacks - which allowed for most of the variation within the daily diets of those I worked with. Dosas and idlis - both made with fermented black gram and rice, 
Pre-publication version of 'Civilising tastes: from caste to class in South Indian foodways' in Food Consumption in Global Perspective: Essays in the Anthropology of Food in Honour of Jack Goody. Editors: Klein JA, Murcott A. 65-86. Palgrave Macmillan, New York 2014.

one fried, the other steamed - were the most popular, and, because they were labour intensive to prepare, were often bought in from village tiffin or tea shops, along with the peanut or coconut chutney and special chilli powder with which they were usually served, or were prepared communally by neighbours, using shared grinding stones. Sweetmeats such as Mysore pak, kaja and peanut clusters - non-milk based and cooked in ghee, so with a longer shelf life than those available fresh in the local bazaar - were also available in the teashops, along with salt biscuits and branded boiled sweets and toffees (which were mostly the preserve of children), betel nut and cigarettes.

Men, in particular, often ate their dosas and idlis in the teashops along with their morning tea, a glance at the newspaper and a chat with their friends and neighbours. They would then take additional supplies back home for the rest of the family. Other breakfasts prepared at home, not common in teashops or restaurants, included ragi java (a thin brown porridge made from red or finger millet) and upma (a thicker porridge made from semolina and flavoured with curry leaves, peppercorns, mustard seeds and green chillis).

In the evenings, there were additional stalls in the centre of the village (and, outside, lining the roads to the nearby town) touting fried savouries, including chilli bujjis (green chillis fried in a gram flour batter and served with finely chopped red onion and squirts of lime juice) pakodis (chopped onion and, sometimes, other vegetables, fried with curry leaves in a crisp batter) and potato bonda, eaten in the street by men and sometimes taken home in newspaper parcels to their families. These and non-vegetarian deep-fried snacks, such as spiced chicken and fish, were also noted as favourites to accompany liquor. 
Pre-publication version of 'Civilising tastes: from caste to class in South Indian foodways' in Food Consumption in Global Perspective: Essays in the Anthropology of Food in Honour of Jack Goody. Editors: Klein JA, Murcott A. 65-86. Palgrave Macmillan, New York 2014.

Few of the older generation, either in Bethany or in the local town, ate main meals out unless they had to, and women in particular seldom ate rice-based meals in restaurants. When they worked as labourers in the fields they tended, like the men, to take steel boxes of either pulihora (fried rice preserved with lemon or tamarind) or curd rice and pickle, the same kind of food prepared for long train journeys. Women did, though, partake of tea, sweets and fried snacks if they were brought back for them, both from within the village and from the bazaar. My own cook, for example, would often ask me to bring her a portion of badam palu (almond milk), chivda (a savoury mixture of fried pulses, nuts and chickpea flour noodles) or fresh milk sweets if I was going to the bazaar to sustain her during one of her twice weekly fasts (during which she forwent a full rice-based meal but, as was quite common, ate other foods). They also took drinks, including the iced fruit juices and sherbets that were available in the bazaar and, occasionally, bottled soft drinks, which recently had become available in smaller, and therefore more affordable, bottles. Such foods, while adding variety to the diet, were nevertheless seen as peripheral to the main food events of rice, curries and curd, and when people asked if you had eaten they always meant rice.

Given the culinary conservatism the above implies, it is difficult to envisage the fluidity in dining arrangements required to use food as a signal of class distinction. As Goody (1982: 36) reminds us, however, diet has always evolved in relation to a nexus of circumstances, and although rice has been cultivated in India since at least the third century AD (Achaya 1994: 44-45), even forty years ago, as many older informants attested, it was not available in the quantities it is today, even though for most it remained the ideal. My 46-year-old friend Kumari, who originally came from the more 
Pre-publication version of 'Civilising tastes: from caste to class in South Indian foodways' in Food Consumption in Global Perspective: Essays in the Anthropology of Food in Honour of Jack Goody. Editors: Klein JA, Murcott A. 65-86. Palgrave Macmillan, New York 2014.

arid Andhra region of Rayalseema, recalled for example that the midday meal in the rural household she grew up in was always sangati - a solid dish combining ragi (finger millet) or, in some areas, jonnalu ${ }^{6}$ (sorghum) with, at that time, hand-pounded rice. Many of her elders back in her natal village still ate the dish in preference to boiled rice, but those of her generation and younger seldom chose it these days, and I was never offered it. Her husband Jawaharlal, who came from a farming village near Bethany in coastal Andhra, also ate some sangati as a child, although rice - again, hand pounded rather than mechanically processed in a mill, as it was nowadays - had been more readily available than in other areas. So too, he said, were the small fish that could be had in abundance from the paddy fields. Alongside chutney and green chillis they made up the bulk of his diet. Pesticides and contemporary farming methods, he lamented, had put a stop to that particular source of protein.

Both Jawaharlal and Kumari, along with the bulk of those I worked with, were growing up at the onset of the so-called Green Revolution (see, e.g., Frankel 1971) in the mid-to-late 1960s, kick-started in Andhra by - as many informants made reference to -the completion of the Nagarjuna Sagar dam in 1967, a major hydro-electric and irrigation project. It was the improved irrigation brought by the dam, coinciding with a more widespread investment in tools, fertilizers and seeds, that led to a vast increase in rice production ${ }^{7}$ and, with it, mills that industrialized the de-husking process.

More recent changes in dining appeared less radical, in that the basic structure of a meal eaten in the home has remained fairly consistent, across classes as well as castes, over the 28 years I have been visiting the region. There had, however, been important variations at the peripheries - in terms of the food eaten outside the context of 
Pre-publication version of 'Civilising tastes: from caste to class in South Indian foodways' in Food Consumption in Global Perspective: Essays in the Anthropology of Food in Honour of Jack Goody. Editors: Klein JA, Murcott A. 65-86. Palgrave Macmillan, New York 2014.

household meals - as well as changes in attitudes towards food and presentation. The main shifts, it became apparent during my fieldwork in the summer of 2011, were generational, and were concerned with what most people still referred to generically as tiffins. Idli and dosa or the deep-fried South Indian snacks I described above remained popular across the board. Those under the age of 30 , however, had been sensitised to other culinary opportunities through media, education, a greater range of choices and wider social contacts than had been available to their parents' generation, and so were also more adventurous in their tastes. Chinese-inspired dishes - such as fried noodles and cauliflower or chicken Manchurian, all served with bottled soy and sweet chilli sauces - were especially popular, as were local versions of pizzas and (vegetarian) burgers. Fifteen years ago, none of these items were locally available: the most exotic items on offer then were the processed cheese and white bread sandwiches sometimes available at the railway station (and marketed predominantly at those passing through).

With the opening of a new restaurant in the mid-1990s, not only did these dishes become readily accessible in the local town, but a relatively respectable space was provided in which both young men and women could socialise beyond the confines of their households ${ }^{8}$. Unlike the utilitarian and mostly vegetarian 'meals hotels' in the centre of town or clustered around the bus station - where standard set-meals were quickly served and eaten, in near silence by the diners - customers at the new, non-veg restaurant could take their time over snacks or meals and bottled cold drinks, shielded from the main thoroughfare in an enclosed courtyard or kept cool in the air-conditioned 'special room'. Like the Delhi coffee chains described by McGuire (2011: 120), this was a place for conspicuous consumption. In addition to South Indian 'meals', north- 
Pre-publication version of 'Civilising tastes: from caste to class in South Indian foodways' in Food Consumption in Global Perspective: Essays in the Anthropology of Food in Honour of Jack Goody. Editors: Klein JA, Murcott A. 65-86. Palgrave Macmillan, New York 2014.

Indian dishes incorporating unusual ingredients like mushrooms, peas and paneer (cheese) were also on the menu, as were Chinese dishes and a limited range of Western specialties, such as sandwiches and 'finger chips', available with tomato ketchup. As well as a haven for a visiting anthropologist, the new restaurant also proved popular among local business people with clients to entertain and, in particular, with the student population.

Most of the young people I knew at the time could not afford to go to the restaurant very often if at all, and when they did it was usually to share a small bottle of Pepsi with two or three friends from college. When takeaway stalls and other, cheaper outlets selling similar types of food proliferated in the years ahead, however, they were already knowledgeable about what was being offered. 'Our parents won't eat this kind of food because they don't know about it,' as one 19-year-old girl explained to me when I asked her about her diet. 'We'll eat things like pizza when we're out with college friends, or chicken noodles and Manchurian, or maybe mixed fried rice. There are so many places in town where you can get that kind of food now - maybe 50 take away joints. It's just what we do on special occasions and celebrations, like a friend's birthday, for example.' Others told very similar stories, adding that they had taken to eating such food along with their fellow students when they lived in college hostels. Take away outlets also enabled girls from more conservative families - those who would not have allowed them to go alone with their peers to a restaurant - to partake of such food.

Although those in their mid-30s and above have been more reticent about trying the new dishes on offer, they have nevertheless been affected by the increase in 
Pre-publication version of 'Civilising tastes: from caste to class in South Indian foodways' in Food Consumption in Global Perspective: Essays in the Anthropology of Food in Honour of Jack Goody. Editors: Klein JA, Murcott A. 65-86. Palgrave Macmillan, New York 2014.

numbers of relatively cheap take away stalls and 'curry points', from which it is also possible to purchase a plastic bag of sambar or other curry - enough to stretch around a family when combined with pickles - for around Rs10. In just the last two years, I discovered, it had become common for many households to buy in takeaway portions to supplement their home-made cuisine once or twice a week. This had simultaneously enhanced choice within households - if members did not like what was on offer they could have something brought in - and, in a small way, so far, freed up time for women that was otherwise spent cooking. Among some women, particularly those under 50, there had also been a slight drift away from simply replicating or embellishing the dishes their female kin had taught them, to experimenting with recipes in books, magazines and on the television and, as I shall elaborate on more in the next section, to presenting their food, at least to outside guests, in what they considered more modern and socially prestigious ways.

Some of the changes I have described here have undoubtedly been brought on by the increased flow of goods and ideas that liberalisation had permitted. Such developments as an improved electricity supply and the availability of privately-owned generators, which have allowed caterers to invest in freezers and thus offer a wider range of food choices, alongside an intensification of farming and an increasingly literate population, have likewise played their part (see also Goody 1982: 99). The several ice-cream parlours that now populated the main streets of the local town, for example, would have been unsustainable at a time when there was no way of efficiently manufacturing, transporting or storing ice-cream, even if consumers had been made ready for it through mass media. What I am interested in here, however, is how these 
Pre-publication version of 'Civilising tastes: from caste to class in South Indian foodways' in Food Consumption in Global Perspective: Essays in the Anthropology of Food in Honour of Jack Goody. Editors: Klein JA, Murcott A. 65-86. Palgrave Macmillan, New York 2014.

changes, alongside more subtle alterations to domestic and celebratory meals, have been used by those I worked with to signify class, and/or to distinguish themselves as being more civilised and cultured than others. It is to this that I now turn.

\section{Class and food in provincial Andhra Pradesh}

In the public sphere, the small town restaurants and the takeaway joints I have described offered new and evolving contexts in which identities and status could be struggled over and asserted. In offering 'foreign' dishes - not just Chinese and Western but also unfamiliar specialties from other parts of India - the food served up in such places to some extent broke free of the references to caste inherent in everyday domestic cuisine, and enabled a commensality based on other factors. In the domestic context, the presence or otherwise of heating alliums, masalas and meat or eggs, or the complexity of the meal, alongside concerns about who cooked the rice and the order in which people might eat, are all heavily coded with caste. Food taken from the home to share with others outside could also be problematic for the same reasons. My friend John Paul, a tailor from an ex-untouchable caste, complained to me that when he took festival sweetmeats prepared by his mother to share with colleagues at the shop he worked in, most of them made excuses not to eat them. They would not say so explicitly, he told me, but he was sure it was because they were all from higher castes than he was.

In contemporary food outlets outside the home, in contrast, where food was externally prepared and seen as separate from domestic cuisine; usually fried rather than boiled (so less susceptible to being polluted by the cook); and the items on offer sat outside usual classifications, those sharing it could do so on an equal footing, their 
Pre-publication version of 'Civilising tastes: from caste to class in South Indian foodways' in Food Consumption in Global Perspective: Essays in the Anthropology of Food in Honour of Jack Goody. Editors: Klein JA, Murcott A. 65-86. Palgrave Macmillan, New York 2014.

relative status not defined by caste differences but by their shared capacity to partake of modernity and to consider themselves 'educated'. For example, non-vegetarian food, in such contexts, might reference high class status, in contrast to the still persistent idea that vegetarianism might increase caste status (Srinivas 1952: 226, cited in Goody 1982: 115; Desai 2008). Local student parties in their shared hostels operated in a similar way: the snacks served - either fried takeaway items or, more commonly, shopbought western-style cakes (sweet), chivda/mixture (savoury) and bottled fizzy drinks allowed for a commensality that was both 'safe" ${ }^{\text {9 }}$ and cosmopolitan. For youth I knew in the village, partaking in these kinds of food sharing events signalled generational differences and a 'youth culture' that was imperceptible back in the 1980s, when there appeared less to differentiate food consumption across generations. They also gave them identities that simultaneously separated them from their peers who did not attend school or college but worked for daily wages in the fields or local factories, and forged and sustained new relationships with their fellow diners. Drawing on the criteria used by the likes of Fuller and Narasimhan's (2007) successful IT professionals to define themselves as middle class - education, aspiration and cosmopolitan consumption these young men and women identified themselves, even when they fell short of the ideal, in relation to the growing urban middle classes.

While partaking in the modern foods that globalization, industrialization of production and economic liberalisation had made possible was an important part of this social positioning, simply eating noodles or pizza with friends was not in itself sufficient to warrant social elevation. Demonstrating that one was educated and modern - pre-requisites to performing new middle classness - also required corresponding 
Pre-publication version of 'Civilising tastes: from caste to class in South Indian foodways' in Food Consumption in Global Perspective: Essays in the Anthropology of Food in Honour of Jack Goody. Editors: Klein JA, Murcott A. 65-86. Palgrave Macmillan, New York 2014.

postures and styles, and these were also best learned and shown-off through public consumption. Eating out at traditional 'meals hotels', while also public, was an essentially individualised affair: diners eat quickly with minimal conversation, their faces turned to their food rather than their fellow diners. Background noise is provided by the clatter of stainless steel thalis and bellowed demands for more rice and sambar rather than, as is the case in the newer style of food outlet, the chatter of fellow diners, who take more time over their food. 'In the West you sip your drinks,' an older village friend once said to me as he watched me drink a glass of beer during an all-male social event. 'I've seen it in American films. Here, we pour it down as quickly as possible!' The student generation, however, was also more likely to sip its drinks - at least their Coca-colas or Limcas ${ }^{10}$ in ice cream parlours and other social eating places - and masticated its snack food slowly and deliberately. The opposite style of eating - using the full palm and not just the finger tips to combine the rice with the curry; throwing the food into one's mouth rather than placing it there; face down turned towards the plate; eating with an open mouth and spitting out unwanted stems, pods and pips directly on to the floor; and openly belching at the end of a meal - was described to me by one informant, a middle-caste ranking woman in her 40 s, as 'a very low caste way of eating' (Staples 2008: 48). Others of comparable status made similar remarks throughout my fieldwork. Her reference was to caste rather than class, but in as much as her disparaging comment referred to a performance rather than an intrinsic quality ${ }^{11}$, it could - through practice, conscious or otherwise - be changed. And this was precisely what happened among my younger informants as they learned to conduct themselves in particular ways through shared dining experiences with their peers. Through the dining 
Pre-publication version of 'Civilising tastes: from caste to class in South Indian foodways' in Food Consumption in Global Perspective: Essays in the Anthropology of Food in Honour of Jack Goody. Editors: Klein JA, Murcott A. 65-86. Palgrave Macmillan, New York 2014.

experiences afforded by the new contexts that were opening up in small towns throughout the region where I worked, the relatively educated descendants of rural peasant and labouring classes could lay claim, through the cultivation of certain styles, to something akin to middle class status. This middle class more broadly established and identified itself by, as Liechty puts it, 'engaging in cultural practices that weave together cultural paradigms... such as caste-oriented notions of prestige, orthodoxy and propriety and new market-driven, mass-mediated values and desires' (2005: 3). Those I worked with often lacked the economic means fully to sustain the lifestyle this required, but food-sharing events with their classmates enabled them to embody the appropriate values and to perform them successfully in particular contexts. In doing so, I argue, they used food to play around with the class-based categories that might otherwise have excluded them.

Even a more conservative older generation, for all its benign bemusement at the youthful penchant for stir-fried noodles and pizza, did not remain untouched by what was happening in the world beyond their own domestic settings. As noted above, the ready availability of keenly priced savoury accompaniments to rice-based meals from 'curry points' had already allowed for a diversification of tastes within households and to free up women's time (see Staples, forthcoming). The greater availability of ingredients in the market and shops - combined with widespread bottled-gas provision over firewood for cooking, and products, like rice, that had already been mechanically processed before purchase - also enabled the preparation of a wider range of dishes than in the past. These factors had so far had only a small impact on most household's dayto-day diets, but changes, particularly in the ways hospitality was performed, were more 
Pre-publication version of 'Civilising tastes: from caste to class in South Indian foodways' in Food Consumption in Global Perspective: Essays in the Anthropology of Food in Honour of Jack Goody. Editors: Klein JA, Murcott A. 65-86. Palgrave Macmillan, New York 2014.

noticeable when I was invited for dinner. During my earliest visits to the village, on such occasions I was mostly fed separately from other family members; the latter either waited outside or were involved in the cooking and serving. I would typically be seated on a mat inside the house, and served by my host onto a steel plate from central pots of rice (in very large quantities); a main non-vegetarian curry ${ }^{12}$; possibly dhal or sambar; and usually curd and pickle. This would invariably be followed by a steel tumbler of semiya (a runny milk-based sweet with vermicelli, dried fruit and coconut). My host would check on me intermittently as I ate, topping up my plate until I protested with sufficient force that I could eat no more. In a few households, I was still fed like this, but, increasingly, social dinners have drawn inspiration both from media and from the local restaurants I have described. In terms of food provided, the number and variety of side dishes has increased and, rather than being served from central pots, are these days more likely to be offered in smaller, individual serving dishes lined up alongside my plate - now often china or plastic - along with rice and sometimes chapattis. A shop bought milk sweet, some chivda or potato crisps might precede the meal, and fried coconut rice or pulihora would frequently be offered before boiled white rice. Dessert, more likely now in a glass bowl than a steel tumbler, was usually still vermicelli and milk-based, but these days was prepared in a variety of ways, with greater attention given to presentation. Bananas, mangoes or less common fruit - such as apples - might also be offered to end the meal. I was often provided with a bottle of mineral water (previously unavailable) rather than water drawn from the municipal tap or, as in the past, from the well, and increasingly I would be seated on a chair at a tablecloth-covered 
Pre-publication version of 'Civilising tastes: from caste to class in South Indian foodways' in Food Consumption in Global Perspective: Essays in the Anthropology of Food in Honour of Jack Goody. Editors: Klein JA, Murcott A. 65-86. Palgrave Macmillan, New York 2014.

table rather than on the floor. Bottled fizzy drinks, now available cold from neighbours with fridges, would often be offered at the end of the meal.

Perhaps the biggest change, however, is that my hosts are now much more likely to remain in the room while I eat, with male members of the household - and in one or two cases even the women - sometimes eating at the same time, often facing me rather than positioned in a line. ${ }^{13}$ The television, once a marker of affluence but now ubiquitous in Bethany houses, would often be turned on, tuned into a foreign station (for my benefit) to a Telugu movie or a music channel. And even though the focus during the meal itself was on eating rather than on conversation, there was considerably more social exchange than there would have been in the past and, because guests had been provided with their own portions in separate serving dishes, there was less sustained pressure to eat more. While this may in part have to do with increasing familiarity between myself those who fed me and/or with their trying to meet the needs of a foreigner, these shifts were nevertheless notable for the ways in which they referenced the modern restaurant rather than the traditional 'meals hotel', while the tableware including flowery plates and glass dessert bowls, available now from fancy stores in the town - mirrored that used by affluent characters in soap operas and films, or depicted in newspaper and television lifestyle advertisements. In the past, the limited range of goods in the local market restricted my informants' capacities to do this, even had the knowledge of such products been there, but market reforms have made available a much wider range of goods, including cheap replicas of items perceived as prestigious, through which small differentials in status might be asserted. Plastic moulded tumblers designed to resemble crystal glassware, for example, locally spoke of greater 
Pre-publication version of 'Civilising tastes: from caste to class in South Indian foodways' in Food Consumption in Global Perspective: Essays in the Anthropology of Food in Honour of Jack Goody. Editors: Klein JA, Murcott A. 65-86. Palgrave Macmillan, New York 2014.

sophistication than the conventional stainless steel cups even if, on a broader stage, they might also be perceived of as examples of 'bazaar-kitsch' (Pinney 1995). In short, the provision of such meals and the way in which they are hosted said something about how the hosts saw themselves and wanted to be seen in terms of social status, a development made possible through wider socio-economic and political change.

Further referents for how the village families I worked with communicated status through entertaining were the weddings and other celebratory feasts put on by their more affluent peers in the local neighbourhood. For example, Sri Venkata Reddy, a local businessman who employed a couple of colony members and served as a trustee of a local NGO that supported some of the community's welfare programmes, hosted a vast lunch for 4,000 diners to mark the completion of his new house to which I was invited. Served in sittings on long, disposable-tablecloth-covered trestle tables arranged in the street in front of his new house, even those who were not invited appeared to be well-versed in what was being served and how, several sharing with me the cost of the gold-foil covered disposable plates ('Rs4 each piece!') and other items associated with the meal. Diners were served appetisers of crisps, chivda and sweetmeats, followed by a seemingly endless range of vegetable fries and curries (I lost count after the first ten), incorporating exotic vegetables and cooking techniques from other parts of India; two types of rice, enriched with ghee; sambar, dhal and rasam; several chutneys; curd and raita; poppadoms; bananas; a sweet payasam; and - as a digestive - sweet paan.

Although the quantities of food served were so vast as to render much of the meal inedible (in some ways it was more of a potlatch than a dinner) as a statement of Venkata Reddy's status and economic success the feast, spoken of in awe for a long 
Pre-publication version of 'Civilising tastes: from caste to class in South Indian foodways' in Food Consumption in Global Perspective: Essays in the Anthropology of Food in Honour of Jack Goody. Editors: Klein JA, Murcott A. 65-86. Palgrave Macmillan, New York 2014.

time afterwards by many of those I worked with, achieved its purpose. Most of my informants could not hope to compete in terms of scale, but some of the more economically well-placed among them could replicate elements of the meal and its structure in hosting their own celebrations.

Finally, my village-based informants also attempted to assert superior status by negative comparisons with those caricatured as 'the poor' and 'the uneducated'. Attending a celebratory meal at the house of a family of rag pickers in Hyderabad during my fieldwork in 2006, for example, my research assistant Das - himself a leprosy-affected man who lived in Bethany - warned me not to raise my expectations. 'These kind of people,' he said - conflating caste, class and education in that single phrase - 'won't know how to cook or serve in a proper way. Back in Bethany we've had more exposure, more education, but these people haven't had that.' In the event, although the food tasted fine to me, there was only one curry, served direct from the cooking vessel to the plate, and it was accompanied with a strongly spiced pilau rice heavy with oil; food which, from Das's point of view, lacked refinement.

In a similar distancing of themselves from those with less sophisticated tastes, when I accompanied a group of young village men from Bethany on a sponsored cycle ride through the state, fed along the way by various small NGOs and Rotary Clubs, the quality of the food was often a source of consternation. ${ }^{14}$ The men were visibly offended after being given, at one of our stops, a meal that was considered 'the kind of thing they might eat in very poor villages.' The low quality of the meat, the lack of subtlety in the spicing, and the thinness of the dhal had been taken to convey a lack of respect from the host. Here, then, it was not that the food offered reflected the low status 
Pre-publication version of 'Civilising tastes: from caste to class in South Indian foodways' in Food Consumption in Global Perspective: Essays in the Anthropology of Food in Honour of Jack Goody. Editors: Klein JA, Murcott A. 65-86. Palgrave Macmillan, New York 2014.

of those who offered it; on the contrary, it suggested to the diners that their hosts had considered them as a low status group to whom roughly spiced curries made with the cheapest ingredients would be acceptable. The village men had rejected this classification through their sullen response to the meal - they ate silently and refused seconds - and their eagerness to leave as soon as we had eaten.

In short, then, for the people I worked with - even the youth who had been fortunate enough to complete college and get jobs - the middle-class was generally understood as being other people, elsewhere. Nevertheless, in mimicking their styles and tastes and, in so doing, embodying them, they succeeded, at various points, in blurring the social boundaries between themselves and their wealthier, urban peers. Buying into a system that judged them on their social sophistication - their capacity to perform the values of the 'educated' and the 'modern' - rather than their birth-ascribed status, also offered them greater opportunities for social elevation.

\section{Conclusion}

When Goody published Cooking, Cuisine and Class (1982) 30 years ago, the ambitious sweep of his approach took the anthropology of food beyond a contest between materialist and symbolic explanations to demonstrate just how far the symbolic and the material are each constitutive of the other. He showed how a multiplicity of concerns from the local to the global, from beliefs about the ritual purity of food to the processes of production and distribution - variously converge to constitute and shape particular foodways. As such, anthropologists need to be attentive to the relationships between consumption, production and the socio-economic order; the constraints they might 
Pre-publication version of 'Civilising tastes: from caste to class in South Indian foodways' in Food Consumption in Global Perspective: Essays in the Anthropology of Food in Honour of Jack Goody. Editors: Klein JA, Murcott A. 65-86. Palgrave Macmillan, New York 2014.

impose on what and how people eat; and external socio-cultural influences. In addition to how food is produced our investigations also need to explore how it is then distributed and prepared, and the contexts in which it is then eaten. Taking a cue from Goody, I have attempted to be mindful of these wider influences at the same time as zooming in on the specific eating practices of those I worked with, and to trace the multiple implications of the former for the latter.

Goody was also correct to point out that food in India is culturallydifferentiated: not just in terms of a high and a low cuisine - which his broad brush, comparative approach illuminates - but also in multiple ways across different social contexts to demarcate more subtle differences in terms of status and identity, and, asserted proactively, to bring about change in one's social position. Specifically, I have attempted to chronicle how changes in what people consume in South India have been changed by two major recent historical shifts over the past half century. The first was the Green Revolution and the technologies that have sprung from it, which occurred from the late 1960s onwards. This has led to an increasing industrialisation of food production, and helps to account for, among other things, the widespread availability of rice - mechanically de-husked as opposed to hand-pounded - and significant changes in the relative costs of different types of meat. Hand-in-hand with these developments in farming have been advances in technologies and infrastructure which have, for example, made possible the distribution of food stuffs over greater distances - and therefore the introduction of 'exotic' ingredients to places where they were not previously available and a sufficiently stable electricity supply for restaurateurs to incorporate frozen ingredients into their dishes. Secondly, the market reforms that have occurred since the 
Pre-publication version of 'Civilising tastes: from caste to class in South Indian foodways' in Food Consumption in Global Perspective: Essays in the Anthropology of Food in Honour of Jack Goody. Editors: Klein JA, Murcott A. 65-86. Palgrave Macmillan, New York 2014.

early 1990s have made for the availability of a greater range of goods through which distinctions might be expressed, and a greater flow of images and ideas that have informed how the wider selection of material goods might be channelled into the cultivation of new identities. The incorporation of Chinese and so-called continental items into the diets of some people in provisional towns, for example, is an indication of how material and technological changes have been harnessed in the expression of cosmopolitan tastes, while replicating the dining styles illustrated in television and magazine advertisements would simply not have been possible prior to the mass production of melamine plates and crystal-effect glassware.

As I have also attempted to show, however, these macro-structural shifts and the kaleidoscope of effects they have at micro-level, do not simply impose mechanistic responses in what and how the people I worked with ate. Rather, they opened up, and/or constricted opportunities to constitute identities through food that people responded to in divergent ways. The kinds of material changes I have outlined above are variously used to assert, redefine, and contest existing social categories and to create new ones. Young people with access to a college education from relatively poor backgrounds, for example, were seizing the opportunities presented by 'modern' foods that incorporated 'exotic' ingredients to replicate the styles of a young, urban middle-class to which they were exposed via media (film, advertising, the internet and social media) and, when they or siblings went to study in outside colleges, via direct experience. This also facilitated the learning and embodiment of styles, habits and manners through which middle-class qualities might more effectively be performed. The bodily dispositions associated with low-caste status - deferential movements; down-turned heads; bodies 
Pre-publication version of 'Civilising tastes: from caste to class in South Indian foodways' in Food Consumption in Global Perspective: Essays in the Anthropology of Food in Honour of Jack Goody. Editors: Klein JA, Murcott A. 65-86. Palgrave Macmillan, New York 2014.

literally bent downward through years of prostrating themselves in front of their putative superiors; and uncultivated styles of eating - were replaced, through alternative practices, with more confident, relaxed and open-movements, dress styles that mimicked expensive fashions, and the increased screening-out of what Douglas called 'irrelevant organic processes' (1996: 76) during eating to provide contexts in which 'civilised' social intercourse could take place ${ }^{15}$. Young families, too, adopted similar styles in hosting dinners for outside guests - such as myself - that also showed them to be 'modern' and 'educated': terms associated with middle class membership.

Although the engagements with food I have described allowed for a greater fluidity in social status, in closing it is also worth noting that while mimicry of urban middle class identities enabled more of my informants to negotiate their relative status than might have been possible in the past, such strategies were not open to everyone. The comment that 'the middle class gets bigger and richer but those at the bottom are still as poor as ever they were' was made, in as many words, by so many of my informants that it became a cliché: in order for some to increase their status it remained necessary - as some of my ethnographic examples also make clear - to have the poor, the uneducated, and the uncouth as reference points against which to measure their own elevation. And in a milieu where there were more foods, more recipes, more styles of eating and presentation - as well as a limiting of animals and fish once free for the hunting and of land available for public grazing - not having access to the discourses of social sophistication made those at the bottom of the heap all the poorer.

\section{$\underline{\text { End notes }}$}


Pre-publication version of 'Civilising tastes: from caste to class in South Indian foodways' in Food Consumption in Global Perspective: Essays in the Anthropology of Food in Honour of Jack Goody. Editors: Klein JA, Murcott A. 65-86. Palgrave Macmillan, New York 2014.

${ }^{1}$ In rural Andhra Pradesh, for example, my informants recognised members of Kapu and Reddi castes - both from the Sudra, or lowest, varna - as socially important because they owned a disproportionate amount of farming land compared to other castes.

${ }^{2}$ Although not exclusively: Fuller and Narasimhan (2007: 135) note that the IT professionals they worked with in Chennai did not exhibit the anxiety commonly attributed to those of their social strata

${ }^{3} 58$ per cent of households questioned in a survey I conducted in 2011.

${ }^{4}$ See also Harriss-White, 2004, for more on subsidised food in the neighbouring state of Tamil Nadu.

${ }^{5}$ For confirmation of this ordering see also Chitra Banerji's evocative descriptions of Bengali cuisine (2008:xv; 3-28).

${ }^{6}$ Sorghum was more popular among those I knew from Cuddapah and from Rajamundry, both slightly north of where Kumari came from, where I was told it grew particularly well. In both places, I was told, rotis - flat bread - were also made from sorghum flour.

${ }^{7}$ See the Rice Knowledge Management Portal - www.rkmp.co.in -- accessed 5 January 2012, which, in addition to providing trends in rice production across India, also records how developments in rice production were managed first by the All India Co-ordinated Rice Improvement Project in 1965, and from 1975, by the Directorate of Rice Research. ${ }^{8}$ There were already bars in the town, but these were exclusively male domains, and even for them were not considered respectable. Even the town's bars, however, are becoming more upmarket and comfortable, suggesting that they, too, are taking cues 
Pre-publication version of 'Civilising tastes: from caste to class in South Indian foodways' in Food Consumption in Global Perspective: Essays in the Anthropology of Food in Honour of Jack Goody. Editors: Klein JA, Murcott A. 65-86. Palgrave Macmillan, New York 2014.

from the pub-style bars popular among upper-middle class, cosmopolitan youth - both male and female - in cites like Hyderabad and New Delhi.

${ }^{9}$ Although see also Liechty (2005: 21), who cites an elderly Nepali mother's warning that eating outside the household 'opens the door to evil spells, spirits and witchcraft.' ${ }^{10}$ Limca, along with Thums Up!, Maaza, Campa Cola and Gold Spot were among the Indian brands that dominated the fizzy drinks market prior to the economic reforms of the 1990s. Most of these brands were subsequently bought up by the Coca-cola company and sold alongside its own global brands, with Pepsi as the main competitor.

${ }^{11}$ Even if, as my informant would have argued, it was an intrinsic quality that led to the performance.

${ }^{12}$ This would usually have been chicken or goat although, as I did not eat meat but ate seafood, in my case would have been fish.

${ }^{13}$ Osella and Osella (2008: 186-187) note - following Mayer (1996) - the specifically Hindu practice of diners 'eating sitting in a line, not looking at each other', compared to their Muslim informants who ate together in a large circle.

${ }^{14}$ As I have also discussed elsewhere - see Staples 2008:45.

${ }^{15}$ See also see also Säävälä (2003) - who draws in turn on Bourdieu $(1984,1990)$ - on 'low caste' habitus.

\section{$\underline{\text { References }}$}

Achaya, K. T., (1994), Indian Food: A historical companion, Delhi: Oxford University Press. 
Pre-publication version of 'Civilising tastes: from caste to class in South Indian foodways' in Food Consumption in Global Perspective: Essays in the Anthropology of Food in Honour of Jack Goody. Editors: Klein JA, Murcott A. 65-86. Palgrave Macmillan, New York 2014.

Appadurai, A., (1981), 'Gastro-Politics in Hindu South Asia', American Ethnologist, 8 (3): 494- 511.

Banerji, C., (2008), Eating India: exploring the food and culture of the land of spices. London: Bloomsbury.

Béteille, A, (1996), Caste, Class and Power: Changing Patterns of Social Stratification in a Tanjore Village, Oxford: Oxford University Press.

Bourdieu, P., (1984), Distinction: A Social Critique of the Judgement of Taste, London: Routledge.

Bourdieu, P., (1990), The logic of Practice (translated by Richard Nice), Cambridge: Polity.

Caplan, P., (2008), 'Crossing the veg/non-veg divide: commensality and sociality among the middle classes in Madras/Chennai', South Asia: Journal of South Asian Studies, 31(1): 118-142.

Conlon, F., (1995.) 'Dining out in Bombay', in Breckenridge, C., and Appadurai, A. (eds), Consuming Modernity: Public Culture in a South Asian World, Minneapolis and London: University of Minnesota Press: 90-130. 
Pre-publication version of 'Civilising tastes: from caste to class in South Indian foodways' in Food Consumption in Global Perspective: Essays in the Anthropology of Food in Honour of Jack Goody. Editors: Klein JA, Murcott A. 65-86. Palgrave Macmillan, New York 2014.

Corbridge, S. and Harriss, J., (2000), Reinventing India: Liberalization, Hindu

Nationalism and Popular Democracy, Cambridge: Polity Press.

Daniel, V. E., (1987), Fluid Signs: Being a Person the Tamil Way, London: University of California Press.

Deliége, R., (1999), The Untouchables of India (translated by Nora Scott), Oxford: Berg.

Desai, A., (2008), 'Subaltern vegetarianism: withcraft, embodiment and sociality in central India,' South Asia: Journal of South Asian Studies, 31(1): 96-117.

Dickey, S., (2010), ‘Anjali’s Alliance: Class Mobility in Urban India,' in Mines, D. P., and Lamb, S., (eds.), Everyday Life in South Asia, Second Edition, Bloomington: Indiana University Press: 192-205.

Donner, H., (2008), 'New vegetarianism: food, gender and neo-liberal regimes in Bengali middle-class families', South Asia: Journal of South Asian Studies, 31(1):143169.

Douglas, M., (1996), Natural Symbols, London: Routledge.

Dumont, L., (1970), Homo Hierarchicus: the caste system and its implications, 
Pre-publication version of 'Civilising tastes: from caste to class in South Indian foodways' in Food Consumption in Global Perspective: Essays in the Anthropology of Food in Honour of Jack Goody. Editors: Klein JA, Murcott A. 65-86. Palgrave Macmillan, New York 2014.

London: Weidenfeld and Nicholson.

Frankel, F. R., (1971), India's green revolution; economic gains and political costs, Princeton: Princeton University Press.

Fuller, C. J. and Narasimhan, H., (2007), 'Information Technology Professionals and the New-Rich Middle Class in Chennai (Madras)', Modern Asian Studies, 41 (1): 121150.

Goody, J., (1982), Cooking, class and cuisine: a study in comparative sociology, Cambridge: Cambridge University Press.

Harriss-White, B, (2004), 'Nutrition and its politics in Tamil Nadu', South Asia Research, 24 (1): 51-71.

Lamb, S., (2000) White Saris and Sweet Mangoes: Aging, Gender, and Body in North India, Berkeley: University of California Press.

Liechty M., (2005), 'Carnal Economies: The Commodification of Food and Sex in Kathmandu', Cultural Anthropology, 20 (1): 1-38.

Mahias M. C., (1985), Delivrance et Convivialite: le Systeme Culinaire des Jaina, Paris: Ed. Maison Sei. 
Pre-publication version of 'Civilising tastes: from caste to class in South Indian foodways' in Food Consumption in Global Perspective: Essays in the Anthropology of Food in Honour of Jack Goody. Editors: Klein JA, Murcott A. 65-86. Palgrave Macmillan, New York 2014.

Mankekar, P., (1999), Screening Culture, Viewing Politics: An Ethnography of Television, Womanhood, and Nation in Postcolonial India, Durham: Duke University Press.

Marriott, M., (1968), 'Caste ranking and food transactions: A matrix analysis', in Singer, M., and Cohn, B. S., (eds.) Structure and change in Indian society, Chicago: Aldine: $133-71$.

Mayer A., (1996), 'Caste in an Indian village: change and continuity 1954-1992', in Fuller, C. J., (ed) Caste Today, Delhi: Oxford University Press: 32-64.

Mayer A., (1960), Caste and Kinship in Central India: a village and its region, London: Routledge.

McGuire, M. L., (2011) '"How to sit, how to stand": bodily praxis and the new urban middle class', in Clark-Decès, I., (ed) A Companion to the Anthropology of India, Wiley-Blackwell: Oxford: 117-136.

Nandy, A. (2004), 'The changing popular culture of Indian food: preliminary notes', South Asia Research, 24(1): 9-19. 
Pre-publication version of 'Civilising tastes: from caste to class in South Indian foodways' in Food Consumption in Global Perspective: Essays in the Anthropology of Food in Honour of Jack Goody. Editors: Klein JA, Murcott A. 65-86. Palgrave Macmillan, New York 2014.

Ortner, S. (2003), New Jersey Dreaming: Capital, Culture and the Class of '58,

Durham: Duke University Press.

Osella, C. and Osella, F. (2008), 'Food, memory, community: Kerala as both "Indian

Ocean" zone and as agricultural homeland', South Asia: Journal of South Asian Studies, 31(1): 170-198.

Pinney, C., (1995), 'Moral Topophilia: The Significations of Landscape in Indian Oleographs', in Hirsch E. and O'Hanlon, M. (eds.) The Anthropology of Landscape: Perspectives on place and space, Oxford: Oxford University Press: 78-113.

Reddy, G., (2005), With respect to sex: negotiating hijra identity in South India, Chicago: University of Chicago Press.

Säävälä, M., (2003), 'Auspicious Hindu houses. The new middle classes in Hyderabad, India', Social Anthropology, 11 (2): 231-247.

Sen C.T., (2004), Food Culture in India, Westport, Connecticut: Greenwood Press.

Siegel B., (2010), 'Learning to eat in a capital city: Constructing public eating culture in Delhi', Food, Culture and Society: An International Journal of Multidisciplinary Research, 13: 71-90. 
Pre-publication version of 'Civilising tastes: from caste to class in South Indian foodways' in Food Consumption in Global Perspective: Essays in the Anthropology of Food in Honour of Jack Goody. Editors: Klein JA, Murcott A. 65-86. Palgrave Macmillan, New York 2014.

Srinivas, M. N., (1952), Religion and society among the Coorgs of South India, Oxford:

Oxford University Press.

Staples, J., (2007), Peculiar People, Amazing Lives. Leprosy, Social Exclusion And Community Making in South India, Delhi: Orient Longman.

Staples, J., (2008), “ “Go on, just try some!” Meat and meaning-making among South Indian Christians', South Asia: Journal of South Asian Studies, 31(1):36-55.

Staples, J., (2012), 'The suicide niche: accounting for self-harm in a South Indian leprosy colony', Contributions to Indian Sociology, 46(1\&2): 117-144. 